\title{
Malaria and Sanitation in Colonial Lagos: A Historical Appraisal
}

\author{
Adetiba Adedamola Seun \\ Department of History and International Studies, Adekunle Ajasin University, Akungba, Akoko
}

Email address:

damolascripts@gmail.com

\section{To cite this article:}

Adetiba Adedamola Seun. Malaria and Sanitation in Colonial Lagos: A Historical Appraisal. History Research. Vol. 3, No. 6, 2015, pp. 65-71. doi: 10.11648/j.history.20150306.11

\begin{abstract}
The endemic and devastating nature of malarial fever in Africa in the later end of the nineteenth century is worthy of examination for a number of reasons. First is the fact that the ailment as it adversely affected the colonization process in most British territories in West Africa influenced highly pragmatic policies from the government and the indigenous population. Second is the fact that the ailment attracted a large number of social issues - worthy of mention are the racial and demographic problems generated during this period. This paper investigates and invariably provides a historical explanation to the sanitary policies adopted by the government in one of the earliest British colonial settlements in West Africa, Lagos. In fulfilling this herculean yet intriguing task, this paper relied wholly on archival and written materials.
\end{abstract}

Keywords: Malaria, Environmental Engineering, Policy, Malarial Control, Lagos

\section{Introduction}

Malarial fever was one of the major health problems the colonial government confronted in British West Africa. The high mortality rate caused by the incidence of malaria necessitated the search for measures to curb the scourge. Essentially, the prevalence of malaria in the twentieth century was viewed by most bio-medical scientists as an environmental problem, which could only be contained through the adoption of sanitation measures and the destruction of mosquito-breeding habitats. This view was particularly influenced by the success of the reclamation of land and swamps in the United States of America between 1904 and 1913 during the Panama Canal project which convinced colonial officials of the possible success of such measures in British West Africa. [1] Consequently, measures like the reclamation of creeks and swampy areas, the construction of proper drainage system, the disinfection of waterways, and the proper and regular disposal of refuse were adopted as measures in colonial Lagos. [2] Other measures like the distribution of quinine and other malaria medicines were a subsequent approach that became a consolidation of the precursory work of sanitation.

Although Philip Curtin undermined the success of American health officers in combating yellow fever in Cuba and Panama as raising false hopes for malaria control in
Africa, [3] application of the environmental measure dominated colonial government's policies in the early 1900s. This contradicts Steven Feierman's argument that "none of the authorities - colonial, national or international (as in the case of the World Health Organization) - made full-scale efforts at combating malaria in Africa prior to World War II. [4] It is therefore against this background that this paper examines the various sanitary measures and approaches adopted by the colonial government in the fight against malaria in Colonial Lagos. This paper presents this position under three major themes - Segregated Sanitation: Assessing the Colonial Sanitary Measure in Lagos; Environmental Engineering and Malarial Fever in Lagos; and Malarial Fever, Education Policies and Sanitation in Lagos.

\section{2. 'Segregated Sanitation': Assessing the Colonial Sanitary Measure in Lagos}

In 1897, it was discovered that mosquito was the vector for malaria. As such, the British colonial government started seeking means to eradicate malaria from her colonies in Africa. In 1898, Colonial Secretary, Joseph Chamberlain wrote to the Royal Society [5] to seek its advice on how to control this disease in West Africa. [6] After a visit by its Malaria Investigating Committee, the Royal Society reported that "segregation from the natives is at present the only 
scheme for preventing malaria that offers the least possibility of success in Africa." The rationale behind this was the fact that there was the erroneous belief that the native, particularly native children were the primary carriers of malaria and that since the resources to tackle the ailment was minimal, the only remedy was to segregate Europeans from the natives. Christophers and Stevens argued that, heavily parasitized African children and asymptomatic adults - rather than mosquitoes - represented the greatest danger to Europeans. The isolation of the European sick was futile as long as Europeans and Africans continued to live in close proximity. The infections would continue to be transmitted. [7]

Thus, the very first sanitary approach adopted was for Europeans in Africa to avoid native quarters.

However, unlike what was applicable in other polities in British West Africa, the colonial government in Lagos declined the adoption of such sanitary measure. The governor of Lagos, William MacGregor (1899-1904), who was also a doctor and a colonial health official, disagreed with this policy and instead adopted other public and sanitary measures. According to Thomas Gale, "the governor opposed segregation first of all on health grounds, because its adoption would mean leaving the source of contamination in existence for all time." [8] Therefore, instead of segregation, there was need to cure and eradicate malaria. MacGregor reports his position on the policy:

It is strongly recommended in certain competent quarters that to get away from infected mosquitos (sic), Europeans should live at places apart from the natives. This may be called the academic view. From the administrative point of view it is an unacceptable doctrine. The academic view is ungenerous, and would afford no radical remedy were it practicable, which it is not. The policy followed in Lagos in this as in other matters is to take the native along with the European on the way leading to improvement. Here they cannot live apart nor should work apart and they not try to do so. Separation would mean that little, or at least less, would be done for the native, and the admitted source of infection would remain perennial. To simply protect the European from fever here would make Lagos the great commercial port that it should become. What we can do in this matter for the uneducated part of the Lagos population will be effected chiefly by reclaiming the swamps and administering quinine. [9]

It is right therefore to posit that the first anti-malarial measure adopted in Lagos was the improvement of the environment and to do that, there was need to inculcate into the people a hygienic culture. And that prior to MacGregor's administration, the government in Lagos was still indecisive on the major policies to adopt in transforming the environment of Lagos. Captain G.C. Denton in the 1899 Annual Report, Lagos, pointed William MacGregor's attention to the state of sanitation in the colony prior to 1898;

The question of improving the sanitary condition of Lagos has engaged the attention of the Government for some years past, but, so far, it has not been found possible to devise a scheme likely to give satisfactory results which the colony is able to afford. There are hardly any drains, and what there are are (sic) only to carry off the surface water in wet weather. [10]

In fact, to state how unfortunate things were in Lagos prior to 1898 , the colonial government did not embark on any sanitation scheme. As reflected in the Annual Report, 1898, no amount was spent on sanitation in that year, and only $£ 2,296$ was on sanitation in 1897. [11]

MacGregor transformed the status quo by initiating new sanitation schemes in 1899. First, he commenced his sanitation campaign by introducing hygiene and sanitation courses into the curriculum of local schools. Realizing that the swamps around Lagos were among the most dangerous obstacles to improved sanitation, he proposed and successfully executed drainage projects in several parts of Lagos Township with the aid of the colonial office. For instance in 1899, George Denton, in his report to the Secretary of the Colonies in London unveiled the mode of such policies;

The principal works executed during 1899 were the erection of a new Public Works Wharf, the heightening of filling of the Marina Embankment and the enlarging of the kerosene magazine........ The streets of Island during the year have received special attention; so have also matters sanitary (sic). With regard to the streets, many were remodeled as to surface drainage. [12]

In 1899 , the colonial government spent $£ 21,023$ in executing these projects. [13] While during the period, 19011902 , about $£ 36,303$ was spent on such projects. From 19021903 , about $£ 34,821$ was expended. In 1904, the expenditure has increased to about £59,931. [14] The table below summarizes government expenditure on environmental engineering projects;

Table 1. Colonial Government Expenditure in Lagos

\begin{tabular}{ll}
\hline Year & Expenditure on Public Works \\
\hline $1901-1902$ & $£ 36,303$ \\
$1902-1903$ & $£ 34,821$ \\
$1903-1904$ & $£ 59,931$ \\
\hline
\end{tabular}

Source: Blue Book Report, 1904.

From 1901 to 1902 , the government spent $£ 4,212$ on reclamation projects within Lagos township. One of the most beautiful works of this period was the construction of the new iron bridge over the Five-Cowry Creek, which provided a permanent way from the town to the sea. The cost of the project was £3000.[15] A large portion of Kokomaiko and other swampland in Lagos were partly filled at a cost of $£ 1,874$. [16] In 1903, MacGregor commenced the construction of canal and similar public works in Lagos which he considered to be the most important step to carry out the drainage of the town. The canal, intended as a massive drainage project, was completed shortly and as a result of it, the general public health of Lagos improved significantly. [17] In 1904, the government expended $£ 10,000$ on swamp reclamation. [18] MacGregor's public 
health policy improved the general sanitary state of one of the least unhealthy urban settlement in tropical Africa. His idea was to improve the lives of the entire population, including and eventually relying on indigenous medical help. By 1906, the government had executed reclamation works in Alakoro Swamp, Ajassa, Elegbata, Isale-Gangan, Magazine Point and Idumagbo. Particularly in Lagos Island, owing to the fact that it lies so low, the highest part being only a few feet above sea level with a population of over 70,000, there were several sanitary arrangements carried out during this period. About $£ 4,526$ was spent in swamp reclamation during this year. [19]

However, William Macgregor's successor, Walter Egerton, who became the governor of the amalgamated Colony and Protectorate of Southern Nigeria, launched Lagos into the 'sanitary segregation scheme' when he displaced about 350 Africans from their substantive homes near the Race Course in order to provide a housing area for officials. [20] This removal of Africans from a desirable area of Lagos was as harmful to community relations, ineffective and inappropriate as MacGregor had predicted. Resentment was expressed through petitions, the press, and a sympathetic Member of Parliament in London. The discontent among the African population did not however alter the continuity of the segregation policy in Lagos, like in other polities in British West Africa. By 1909, the Principal Medical Officers of the British West African colonies held their first joint conference, and presented then the basic segregation policy that they wanted followed. All Europeans should be required to live in special reservations separated from the nearest African dwelling by at least 400 yards. This 400 yard neutral zone was correctly calculated to give some measures of security against mosquito-borne diseases.

The proceeding of the conference was however not fully adhered to by the governors of the various colonies on humanitarian grounds. It was only Lugard, in Northern Nigeria, who celebrated the initiative. No wonder, on his emergence as Governor of Nigeria in 1914, he introduced a massive segregation programme in all parts of Nigeria, most especially Lagos. He passed in 1915 a Town Council Ordinance which created 'reservations'. In 1917, he also instituted the Second Town Council Ordinance which attempted to make segregation compulsory in Nigeria. Section 59(b) of the Ordinance made a European liable to pay a fine or imprisonment if he lived in a non-European sector. [21] As Lagos was a polity that fused both European and African populations, the strict adherence to the segregation policy was nothing but a forlorn hope. It is therefore correct to posit that Lagos was one of the first places where the policy became unpopular. Sequel to Lugard's retirement in 1919 and the unpopularity of the policy among the Medical and Public Officials, his successor Hugh Clifford, who was one of the most vocal foes of the segregation policy, discouraged its implementation in Lagos.

Two scholars, on the basis of obviously contradictory reports are at a disagreement on Clifford's response to the segregation policy. The first reflection came from Thomas
Gale in his work, "Segregation in British West Africa". Gale observes that, Clifford reversed Lugard's plans and stated that under his administration no Africans or missionaries would be moved as a result of segregation policies. In 1920, Clifford approved a plan for Lagos that permitted both Africans and Europeans to live at Ikoyi since it was the most logical area into which the native town could expand. [22]

$\mathrm{He}$ was of the opinion that Clifford's administration characterized a drastic decline in relevance of the segregation policy. Ayodeji Olukoju however provides a different perspective as he affirms the continuity of segregation (both on the basis of health and administration) till March 1950, when the Commissioner of the Lagos Colony approved the first African application for a lease at Ikoyi. [23] $\mathrm{He}$ therefore observes that, Clifford years were characterized by adherence to the principle of segregation tempered by circumspection.... By 1921, segregation policy had been redefined to suit the peculiar circumstances of old and new settlements.

In other words, the policy lingered as there was only a change of name, which did not necessarily reflect in the government actions. Carl Nightingale agrees with Olukoju's opinion;

At Lagos, despite Governor Clifford's opposition, local officials managed to set up a largely successful segregated European reservation east of town in a previously unsettled marshy spot known as Ikoyi. Still other segregationists made sporadic attempts to rekindle Lugard's legacy well into the 1930s. However, the Colonial Office gradually abolished the ERAs, finally opening Ikoyi to educated Africans in 1947. [24]

\section{Environmental Engineering and Malarial Fever in Lagos}

Notwithstanding, during Clifford's administration, there was a significant change in the Colonial government's position on both segregation and sanitation. Such that, Medical Officers, declined making such recommendations and proposals that were patterned towards segregation. Instead, in their correspondences and proposals, they stated the need for the government to commence massive environmental and sanitation engineering projects like the construction of drainages, the reclamation of swampy area, disinfection of major waterways; in fact, the re-enactment of William MacGregor's policies. In 1925, the Medical Department in collaboration with the Public Works Department commenced a preliminary survey of the swamps in order to estimate to what extent the construction of proper drainage would reduce the prevalence of mosquitoes. [25] The reclamation of swampy areas, maintenance of ditches and the clearing of bush combined with the use of larvicides such as paris green and fuel oil (kerosene) were adopted. For water in ditches, automatic oilers were employed, using either drip cans or a ball of rags soaked in kerosene. [26] The application of kerosene into holes and ditches was only 
successful during the dry season as it was impossible to apply kerosene to flowing rain water. [27] Therefore in most cases, paris green (a mixture of diesel oil and copper aceto-arsenite) was applied in ponds and ditches in the place of fuel oil.

The use of paris green became a popular anti-malarial measure in the 1930s, sequel to the success of a series of projects by the Rockefeller Foundation in America. Particularly in Puerto Rico, where there was considerable success in the anti-malarial project, the larvicide became so popular and was adopted by the Medical Department in the various British territories in India and Africa. [28] In the 1920 s, the larvicide had been a major feature in the campaign against malaria in India, South Africa and Brazil. The Medical Officer of Health, Lagos, in his annual report for 1931, states that, an experiment was carried out on a pond in Yaba with a view of discovering whether paris green was effectively larvicidal to culicines and anophelines mosquito larvae. After the larvicide was applied, it was discovered that there was no trace of both anopheline larvae for the next six days. Though some culicine larvae were killed, it was discovered that the larvicide failed to completely destroy the premature larvae. Furthermore, it was discovered during subsequent research that paris green was unable to kill adult mosquitoes which fed below surfaces. [29]

This informed the need to intensify routine supervision of sanitation exercises in the residential areas of Lagos. Most of the large towns were inspected by the Deputy Director of Health Service. The use of larvicides in the campaign against malaria took a new turn after the Second World War with the introduction of dichloro-diphenyl-trichloroethane (DDT). In 1941, Paul Muller, a Swiss, synthesized DDT as an insecticide against clothe moths, which frequently feasted on soldier uniforms during military campaigns. [30] The success of the chemical during the war year precipitated its adoption as an anti-malarial tool. The reason for this was that unlike paris green, DDT was used to kill adult mosquitoes and it stayed for a very long time. [31] It subsequently became a regular insecticide used in most parts of tropical Africa. During the second half of the 1940s, public and medical officials in Lagos commenced the regular use of DDT by spraying it in houses and waterways. James Webb reflected on the efficacy of the insecticide as he posited that, "in most areas of seasonal malaria transmission, two applications per year were enough. Where DDT was laid down, the number of new malarial cases plummeted toward zero." [32] In areas like Ikoyi and Apapa, DDT was already noticed on the shelves of several dispensaries and medicine stores by 1952 . [33]

Another major phase of the anti-malarial campaign in Lagos was the regular and proper disposal of waste. This was on the basis that dump sites, especially those located around residential areas, were major habitats of various diseasecausing insects like mosquitoes. [34] In the early 1900s, Lagos was disfigured with several waste places. At first, the government imbibed the village-style sewage disposal system of waste gathering and burning. But as the population of Lagos gradually became dense, there was need to evolve the pail system, which was already in vogue in other colonial settlements in British West Africa. Since Lagos was a firstclass township, the Medical Officers emphasized the need to abandon the native or village system and adopt the public pail latrines. As such, as early as 1925, the colonial government had installed pail latrines on major streets in Lagos. The pails were removed by labourers at night to depots where they were placed on a tramway and taken out to Wilmet Point on the east side of the entrance to Lagos Harbour and emptied into the lagoon in the early hours of the morning. In Ebute Metta district of Lagos, latrine pails were emptied into the lagoon at a dejection jetty built over the lagoon. Normally with ebb tide, the pail contents got carried into the sea, but if the flood tide was running at the time of emptying, considerable quantities of faecal matter were carried back into the lagoon and up Five Cowrie Creek. In the European residential areas, the latrine pail contents were disposed by incineration. Both the public latrines and the system of disposal of the sewage were unsatisfactory. The installation of a water-borne sewage system (as one had already been constructed at a European Hospital in Jos) concurrently with the town planning of the various areas in Lagos Island was seen as reliable alternatives. In Ijora, there was a small automatic flush latrine system in operation at the Electric Power Station, the Public Works Department store, and sawmills. By 1928, a large modern forced draft incinerator was built by one Mr. Heenan and Mr. Froude at Epetedo on Lagos Island.

In 1931, the sewage disposal was improved in some parts of Lagos with the introduction of septic tank installations in some premises in Ikoyi and Lagos Island. [35] In other parts of Lagos, the pre-existing sewage disposal system was adopted. The Medical Department complemented this with regular sanitation exercises which were supervised by the officials of both the public Work Department and that of the Medical Department. These exercises and inspections were carried out particularly in government establishments and stations. Routine sanitary inspections were carried out daily in practically all government stations by African Sanitary Inspectors or Sub-Inspectors. In small stations to which no Medical Officer was posted, the Sanitary Inspector, if there was one was responsible to the local Political Officer. At the larger stations, a European Sanitary Inspector was usually posted. In 1927, seven European Sanitary Inspectors were stationed in the following areas - Lagos Island, Ikoyi, Ebute Metta, Yaba, Apapa, and the Port of Lagos. These inspectors were stationed under the Medical Officer of Health in the Town Council and the Port Health Officer of the Port of Lagos. The Port Health Officer in Lagos was obliged to inspect and prevent mosquito breeding on vessels and other craft within Lagos port. These Health Inspectors were empowered in their operation by two major ordinances - the 1910 Destruction of Mosquitoes Ordinance and the 1917 Public Health Ordinance. [36] Both ordinances provided power and penalties aimed at preventing mosquito breeding. Following an attempt to invoke the power of the courts to a considerable extent, the Principal Medical Officer reported in 
1912 that, in Lagos no summons was issued until offenders had been repeatedly cautioned, yet the number of summons was too great for the capacity of the courts. Some 2,000 applications for summons had to be cancelled. In his report for the years 1919-1921, the Director of Medical and Sanitary Service refers to the impossibility of preventing the breeding of mosquitoes (closely associated with habitation) by punitive measures, and the importance of education and sanitary work by public authorities.

\section{Malarial Fever, Education Policies and Sanitation in Lagos}

Furthermore, in the bid to enhance the efficacy of these inspection exercises, the government introduced intensive three-year training course for prospective sanitation inspectors who would help the medical and public officers already on the field. In 1927, the Medical Officer of Health, Lagos made the training tuition-free and the programme readily available to all prospective sanitary inspectors. Though there was no established facility to accommodate the training of the prospective inspectors, they met frequently in one of the offices of the Medical Officer of Health. During the first and second year, in addition to the course work, the students got practical outdoor training and in their third year were posted to stations where they were under the supervision of a Medical Officer or Medical Officer of Health. During the three-year programme, the following courses were taught: elementary meteorology and mensuration; elementary parasitology and entomology; disinfection and disinfectants; disposal of refuse, nightsoil, drainage; meat, food, and general inspection; water, air and ventilation; rat destruction and anti-mosquito measures; vaccination technique and local legislation affecting public health and elementary vital statistics. Seven of the nine courses offered were targeted at tackling malaria. Furthermore, since 1901, the Department of Public Health, as part of measures to thoroughly train health workers, made it compulsory that all workers within the department attended, though with government assistance, special courses of instruction on tropical diseases, bacteriology and pathology. [37]

In a bid to check the incidence of malaria in government assisted schools, the colonial government embarked on two school-based policies - the inclusion of sanitation into the educational curriculum and the regular sanitary inspection of schools. MacGregor was the first to introduce hygiene and sanitation courses in local schools. Most African students were taught basic sanitation etiquette like hand washing, proper disposal of waste and the need to properly clean the environment. Two courses were taught every day of the week with teachers and students in attendance. [38] The courses were usually handled by medical officers, who in 1931 became regular staff of most government-owned or government assisted schools. School teachers also play a role in the dissemination of hygiene lessons to the students.
This was further elucidated in the 1901 Annual Colonial Report of Lagos;

After attending an elaborate course of lectures on sanitation by the Principal Medical Officer, the teachers of the primary schools subsidized by the government that have been able to obtain by examination First or Second Class Certificates, taught hygiene in their schools. [39]

Students who successfully underwent an examination in the elements of hygiene were usually awarded with a grant. In 1901, the government awarded 388 grants-in-aid. In that same year, the legislature voted $£ 20$ for special prizes to school students that proved themselves most proficient in the subject of sanitation. At the School exhibition, held in December, 1902, 44 school children from seven primary and two secondary schools took part in the competition, and the judges reported that the majority of them showed sound knowledge of the elementary laws of health. [40] The Medical Officers were further apportioned to take up the dual responsibility of providing medical services at the health centre and also, the teaching of hygiene and sanitation to the school community. He was also equipped with the power to take up regular inspection of school buildings and sanitary arrangements and advise teachers and parents on several health issues. [41]

Furthermore, through a collaborative effort between the Education Department and the Medical Department, many schools in Lagos, since 1906 were equipped with model types of incinerators and instituted with simple methods of purifying drinking water supplies with the hope that such practices would be transferred to their various homes. [42] The sanitary measures adopted in schools were further emphasized in 1927 after the Medical Department conducted a survey on the prevalence of malaria among school children. The Medical Officer of Health, Lagos, in his report gave the percentage of children infected with malaria;

The incidence of malaria varies from $9 \%$ to $25.6 \%$ according to the school. Schools situated in the part of Lagos which is close to creeks and the lagoon and liable to engender mosquitoes-breeding, gave the highest percentage of infection. In 1927, fifty-eight schools were visited where it was discovered that most students as a result of the appalling state of the school environment suffered from recurring incidence of malaria, skin diseases like scabies and tinea. [43] This rate of the ailment among school children precipitated the Medical Officer, Lagos to initiate and execute routine inspection of schools.

Apart from the dissemination of hygiene lessons in schools, the colonial government in Lagos also availed other avenues in enlightening the public on the means and methods to contain malaria. Since 1901, the government, through the Medical Department and that of Public Health propagated the knowledge of hygiene in the various communities in Lagos. In 1901 specifically, lectures on sanitation was delivered in some communities in Lagos by Dr. Strachan, Principal Medical Officer, Best and Lumpkin. [44] In most cases in Lagos, cinema films, particularly mobile cinema undertaken by the Health Propaganda Unit of the Medical Department 
was the most common avenue through which hygiene lessons were taught. [45] The cinema, as at 1905/1906 had been a recurring feature in the social life of Lagos. Thus, the unit coopted entertainment with hygiene instruction, which was readily and immediately accepted by the public. Touring with the propaganda van was carried out in several towns within Lagos with an estimated coverage of about 15,000 people in attendance. [46] In the same year, a travelling exhibition was carried in the cinema van and day-time lectures were given to audiences totaling 14,400 people, made up of rulers, their councils, householders and members of staff of the Education Department and Health Department. The lectures consisted of an explanation in simple language of how common diseases like malaria were acquired, and demonstrations were given of simple improvements using local materials, which can be introduced into any home and school at practically no cost. The chief aim of these lectures was to convince the people on the need to adopt hygienic lifestyle.

\section{Conclusion}

As pioneered by William MacGregor in the early 1900s, succeeding governors of Lagos or Southern Protectorate as the case might be, executed a series of environmental and sanitation engineering projects in the eight major areas of Yaba, Ebute Metta, Apapa, Iddo, Lagos Island (West of MacGregor Canal), Ikoyi, Badagry Creek (towards the Light House), and Five Cowrie Creek (towards Victoria Beach). The swamp area within the township was approximately 4,500 acres. Lagos Island particularly was a centre of such projects during this period. Unlike Lagos Island, sanitation engineering projects in Ikoyi were mainly limited to quarters, compounds, and roads. From 1927 to 1929, a considerable area of swamp land was ditched and oiled with a fair measure of success, while in Iddo, reclamation work was carried out in 1927 particularly for industrial purposes. In Badagry however, almost no engineering or reclamation project was carried out. In 1927, the Medical Officer of Health, Lagos proposed the need for a low-cost drainage or other simple engineering measures. His recommendation was probably on the basis that mosquito-breeding in Badagry could adversely affect other districts like Apapa, Lagos Island and Ikoyi, and that such projects would be required in the interest of residents and prevent the infestation of ships. [47] In Apapa and its environs, in the early 1930s, a large portion of swampy areas were reclaimed. Other reclamation followed industrial and residential development. [48] In Ebute Metta, the sanitation engineering project was carried out by the Medical Officer of health and partly by the Railway Medical Officer. Much reclamation project with dredged material was carried out in 1927 between Ebute Metta and Apapa. [49]

These series of projects took a different shape when the colonial government increased her commitment and expenditures on the anti-malarial project. By 1945, the government expenditure on reclamation of swamps and drainage projects had increased such that from 1945-1948, the government spent a sum of $£ 132,000$ on the reclamation of various swampy areas in Lagos. In 1945 specifically, $£ 20,000$ was approved by the colonial secretary for the construction of sluice gates in various swampy areas and canals - Ijora village (£4,568); swamps in Iddo Island $(£ 2,132)$; Five Cowrie Creek, Victoria Beach Area $(£ 13,466)$. The process continued from 1946-1947 with the construction of drainages in Anjorin, Iddo East, Olodi, Sheteolu, and Iganmu. The government approved over $£ 29,200$ on the drainage project that year. [50] The government also constructed new sluice gates in the Apapa canal and refurbished the already existing ones. Customarily, the town engineer was responsible for the construction and maintenance of street drainages, while the Public Works Department and the Railway Department constructed and maintained drainage works in Ikoyi and Ebute Metta respectively.

\section{References}

[1] W.J. Simpson, Report on Sanitary Matters in the East African Protectorate, Uganda, and Zanzibar (Nairobi: Government Printer, 1914), 53.

[2] Amina Issa, "Malaria and Public Health Measures in Colonial Urban Zanzibar, 1900-1956," Hygiea International 10, no. 2 (2011): 35

[3] Philip Curtin, "Medical Knowledge and Urban Planning in Colonial Tropical Africa," in The Social Basis of Health and Healing in Africa, ed. Steven Feierman and John Janzen (Berkeley: University of California Press, 1992), 241.

[4] Steven Feierman, "The Social Roots of Health and Healing in Modern Africa," African Studies Review 28, no. 2/3 (September, 1985): 91.

[5] The Royal Society was established as a research institution that probed into developments and issues related with tropical medicine. Though it was formally instituted in 1907, the institution and its founding members since the nineteenth century, played salient roles in providing important scientific information and advice to the colonial government in British West Africa.

[6] Thomas Gale, "Segregation in British West Africa," Cahiers d' Etudes africaines 20, no. 80 (1980): 496.

[7] S.R. Christophers and J.W. Stephens, "On the Destruction of Anopheles in Lagos," Reports to the Malaria Committee of the Royal Society, $3^{\text {rd }}$ Series (London: Harrison and Sons, 1900), 20.

[8] Gale, "Segregation in British West Africa," 496.

[9] William MacGregor, "A Discussion on Malaria and its Prevention" The British Medical Journal 2, no. 2124 (September 14, 1901), 682.

[10] G.C. Denton to W. MacGregor, "Colonial Annual Report, 1898 " 31 October 1898 , No. 284 of 1898 , Para 5.

[11] Ibid.

[12] George Denton to Chamberlain, "Report on the Lagos Blue Book, 1899” 18 August 1900, No. 321, Para. 17.

[13] Ibid. 
[14] J.J. Thorburn to Lyttelton, "Report on the Lagos Blue Book, 1904," 9 September 1905, No. 470, Para. 9.

[15] Sir W. MacGregor to Mr. Lyttelton, "Report on the Lagos Blue Book, 1903," 19 August 1904, No. 427, Para. 15.

[16] William MacGregor to C.H.H. Moseley, "Colonial Annual Report, Lagos,”30 November 1901, No. 348, Para. 17.

[17] Sir W. MacGregor to Mr. Lyttelton, "Report on the Lagos Blue Book, 1903,” 19 August 1904, No. 427, Para. 15.

[18] J.J. Thorburn to Lyttelton, "Report on the Lagos Blue Book, 1904" 9 September 1905, No. 470, Para. 9.

[19] J.J. Thorburn to the Earl of Elgin, "Colonial Annual Report, Southern Nigeria, 1906,” 21 October 1907, No. 554, Para. 77, 190.

[20] Gale, "Segregation in British West Africa," 497.

[21] Carl Nightingale, Segregation: A Global History of Divided Cities (Chicago: University of Chicago Press, 2012), 179; Gale, "Segregation in British West Africa," 498.

[22] Gale, "Segregation in British West Africa," 504.

[23] Ayodeji Olukoju, "The Segregation of Europeans and Africans in Colonial Nigeria," in Security, Crime and Segregation in West African Cities since the $19^{\text {th }}$ Century, ed. L. Fourchard and I.O. Albert (Paris: Editions Karthala et IFRA, 2003), 283.

[24] Nightingale, Segregation: A Global History of Divided Cities, 188.

[25] Colonial Annual Report, 1925, February 26, 1926, No. 1315, 53.

[26] Report on Anti-Mosquito Campaign, Lagos, December 1929, 22, CSO 26, file no. 15120, National Archives, Ibadan.

[27] Interview with S.A. Akindayo, (Medical Practitioners, Calvary Medical Centre, Mushin), Lagos State, December 16, 2014.

[28] Gordon Harrison, Mosquitoes, Malaria and Man: A History of the Hostilities since 1886 (London: Dutton Publishers, 1978), 186.

[29] Annual Medical and Sanitary Report, Nigeria, 1931, 24, NAI.

[30] Harrison, Mosquitoes, Malaria and Man, 211.

[31] Interview with P.A. Kappo (Medical Director, Abolayo
Hospital, Egbeda, Akowonjo), Lagos State, December 16, 2014.

[32] James Webb, Humanity's Burden, A Global History of Malaria (New York: Cambridge University Press, 2009), 160.

[33] Interview with G. Adetayo (Medical Practitioner), Lagos State, December 16, 2014.

[34] Interview with Wasiu Gbadamosi (Medical Director, Infectious Disease Hospital, Yaba), Lagos State, January 5, 2015.

[35] Interview with S.A. Agboola (Medical Director, Jobi Hospital, Ikorodu), Lagos State, December 16, 2014.

[36] Annual Medical and Sanitary Report, Nigeria, 1927, 26, NAI.

[37] Annual Medical and Sanitary Report, Nigeria, 1931, 25, NAI.

[38] Report on Anti-Mosquito Campaign, Lagos, December 1929, 10 , CSO 26, file no. 15120, NAI.

[39] Annual Medical and Sanitary Report, Nigeria, 1927, 37, NAI.

[40] William MacGregor to C.H.H. Moseley, "Colonial Annual Report, Lagos,” 30 November 1901, No. 348, Para. 13.

[41] Annual Medical and Sanitary Report, Nigeria, 1931, 31, NAI.

[42] Annual Medical and Sanitary Report, Nigeria, 1927, 31, NAI.

[43] Annual Medical and Sanitary Report, Nigeria, 1927, 32, NAI.

[44] William MacGregor to C.H.H. Moseley, "Colonial Annual Report, Lagos," 30 November 1901, No. 348, Para. 13.

[45] Annual Report of Medical Services, Nigeria, 1935, 18, NAI.

[46] Annual Report of Medical Services, Nigeria, 1938, para. 105, NAI.

[47] Report on Anti-Mosquito Campaign, Lagos, December 1929, 14, CSO 26, file no. 15120, NAI.

[48] Annual Medical and Sanitary Report of 1927, 33, NAI.

[49] Director of Medical Service to Chief Secretary to the Government, Lagos, 30 September 1946, CSO 26, file no. $43787 / 55$, NAI

[50] Director of Medical Service to Chief Secretary to the Government, Lagos, 18 April 1947, CSO 26 43787/55, NAI. 